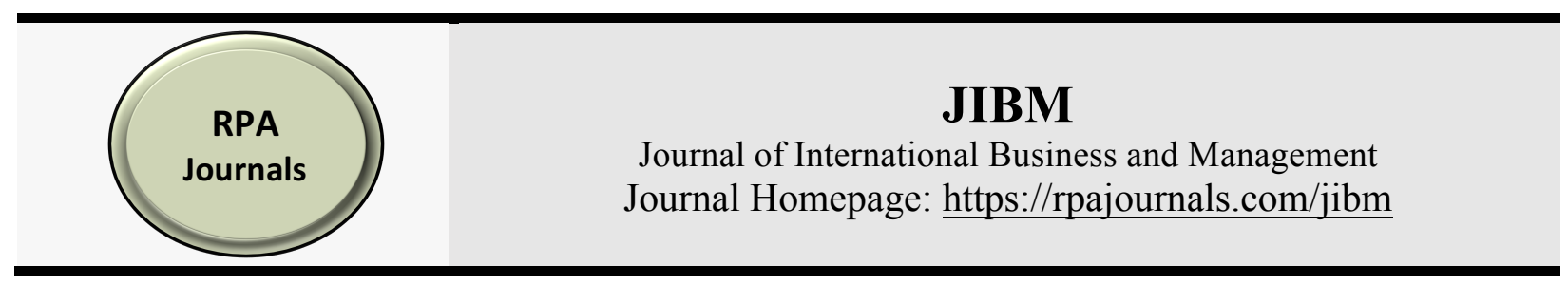

\title{
An Examination of the Relationship between Entrepreneurial Creativity and Firm Performance
}

\author{
Abiodun Tope Samson ${ }^{* 1}$ \\ Doshiro Musa Umar ${ }^{2}$ \\ Kwararafa University Wukari, Nigeria ${ }^{1}$ \\ Nassarawa State University Keffi, Nigeria ${ }^{2}$
}

\begin{abstract}
Entrepreneurial creativity is the generation and implementation of novel and suitable ideas to set up a new business or new program to deliver products / services. This paper examined the relationship between dimensions of entrepreneurial creativity (novelty and meaningfulness) and firm performance. Researches on impact of creativity (meaningfulness and novelty) on firm performance have previously focused on large organizational Contexts, this study proposed the context of SMEs as a better litmus test of this relationship. The study employed a descriptive survey and data were collected from owners/managers of SMEs in Lagos, Nigeria. Having used SPSS statistical tool to carry out regression analysis, the results of the study show that there is positive influence of novelty towards firm performance, and also there is positive significant relationship between meaningfulness and firm performance. This provides a research conclusion that creativity as an intangible resource entrenched within the firm could culminate to sustainable competitive advantage.
\end{abstract}

Keywords: Entrepreneurial Creativity, Novelty, Meaningfulness, Firm, Performance

*Corresponding author: Abiodun Tope Samson; Email: samsontope@yahoo.com

DOI: https://doi.org/10.37227/jibm-2019-04-96

\section{Introduction}

The generation of novel and useful ideas has received an increasing amount of attention in management literature (Amabile, 1996; Hirst, Van Knippenberg, \& Zhou, 2009; Liu, Chen, \& Yao, 2011; Tierney \& Farmer, 2011). Resourceful knowledge has been accumulated about the antecedents of creativity (Shalley \& Zhou, 2008). This growing body of research has always treated creativity and implementation as indicative of the same fundamental concept of innovation. In spite of the prevalent agreement that creativity and implementations are two distinctive activities of an innovation process with potentially different antecedents and consequence (Axtell et al., 2000). Few studies examined creativity and implementation as separate activities and considered their antecedents (Axtell, Holman, \& Wall, 2006; Clegg, Unsworth, Epitropaki, \& Parker, 2002).

Consequently, the major focus on creativity as determinant of innovation, however, has led to too little awareness of aftermath effect of creativity and its firm performance relationship (Gong, Huang, \& Farh, 2009; Shalley \& Zhou, 2008). In spite of the important 
roles of creativity in generating creative ideas at the fuzzy front end of the product innovation process, research on creativity at the team level remains limited (Im et al., 2013). Specifically, there is dearth of evidence that have examined whether creativity enhances firm performance.

Moreover, the pursuit of both creation and implementation are critical to firm performance, it is logical to draw an inference, based on the literature on exploration and exploitation (Bledow, Frese, Anderson, Erez, \& Farr, 2009). Inquisitively however, creation and implementation have not been investigated to know if they work together to influence firm performance. Broad distinction between idea generation and idea implementation was made through stage model (West, 2002). In the course of implementing activities, creative ideas are evaluated, turned into workable products, and incorporated into a firm's practices (Zhang \& Bartol, 2010b).

Similarly, the implementation of ideas that are not creative does not give a crucial advantage to a firm over its competitors (Martins \& Terblanche, 2003). Creative ideas must be implemented to meet internal or external demands and subsequently generate superior performance (West, 2002). Creation without implementation may even hurt a firm's performance because the time, physical energy and financial resources in creative activities might not be regained through the implementation of creative idea (Gong, Kim, Lee, \& Zhu, 2013).

The absence of study on creativity-firm performance relationship might have been caused by the widely held postulation that creativity improves firm performance and no empirical examination is required (Shalley \& Zhou, 2008). Creativity has to be implemented, turned into tangible products, practices and incorporated into operations before it actually enhance firm performance. It is also presumed that direct relationship between creativity and firm performance might not be strong since the implementation of creative ideas is not easy, and creation without implementation might not be useful. Most of the available studies on creativity in management have tended to focus solely on the (product design and features) with no consideration of the role of creativity in associated with firm performance (Im, Montoya, \& Workman, 2013)., other studies, van Esch, Wei, \& Chiang, (2018) studied the mediating role of employees' competencies and the moderating role of climate for creativity, $\mathrm{Wu}$ (2016) examined entrepreneurial leadership, organizational creativity, and firm performance, An, Zhang, You, and Guo, (2018) studied Entrepreneur's creativity and firm-level innovation performance: bricolage as a mediator. Chen, Chang, \& Lin, (2018) explored creative entrepreneurs' happiness: cognitive style, guanxi and creativity and Shahzad, Bajwa, Siddiqi, Ahmid, \& Sultani, (2016) integrated knowledge management strategies and processes to enhance organizational creativity and performance. Therefore, this study takes a radical departure by identifying and examining novelty and meaningfulness as components of creativity that directly translate into improved SMES' performance.

The fundamental objectives of this study are to examine creativity in an organization, entrepreneurial creativity and determine the relationship between dimensions of entrepreneurial creativity (novelty and meaningfulness) and SMEs' performance.

\section{Creativity}

\section{Literature Review}

Creativity has been ranked by about 1500 chief executives across the globe as the most critical leadership quality required for competitive advantage. The report from IBM showed that CEO would craft a creative organization and always equip their entire organization to be catalyst for creativity (Culpepper, 2010). Creativity entails generation of ideas that are 
both novel and useful for practical purpose (Amabile, 1996; Shalley et al., 2004). It is a process of variation, selection and retention of idea that are most promising (Simonton, 2011). The features of creativity could be shown in seeing what everyone else has seen and ability to think what no one else has thought or imaginative activity formed so as to produce result that are original and valuable (Lin, 2011). The production of appropriate and novel ideas through creativity could spring from science, education, business and everyday life (SATHIKH, 2014). Hence, creativity is a precursor of both innovation and entrepreneurship.

Social Psychological model of creativity's process involves presentation of the task or the problem, preparation of stored relevant information, generation of new ideas, validating these new ideas and assess the outcome of each of these ideas (Acharya \& Taylor, 2012; McAdam \& McClelland, 2002). Componential theory of creativity involves an expertise; where it is required that individual needs to possess relevant skills or knowledge in the problem area, creative-thinking skill; the ability to consider different perspectives with intellectual independence and task motivation; which involves Intrinsic motivation for the task to inspire the individual, and for the individual to produce ideas (Amabile, 1998).

Creativity in individual required emotion and intuition (right side of the brain) and generate ideas and logic (left side of the brain) for information gathering (Kao, 1997). Creative individual generally have intellectual and artistic values, always attracted to complex situations, tolerate ambiguity, driven to excellence and endure in difficulty (West, 1997). Those who are more creative and innovative tend to be willing to take risks and violate known paradigms and procedures in order to develop new ideas and solutions. Hence, Creative ideas and their manifestations as products and practices constitute the core of organizational innovation (Martins \& Terblanche, 2003).

\section{Entrepreneurial Creativity}

Entrepreneurial creativity is the generation and implementation of novel, suitable ideas to set up a new business or new program to deliver products / services. The most important novel, useful ideas could consist of the products or services themselves, identifying a market for the products/services, ways of producing or delivering the products/services and ways of obtaining resources to produce/deliver the products/services (Amabile, 1997). The major pre-requisite for entrepreneurial creativity is that novel, appropriate solutions be applied at some point in the process of creating and bringing the product/ service to market. In entrepreneurship, the process of developing creative ideas involves challenging assumptions, broadly scanning the environment, recombining ideas from different areas, tolerating ambiguity, and making novel connection (Zhang \& Bartol, 2010b).

Proactive creativity requires extending effort to widely scan the environment for potentially damaging problems that need solutions. This type of creativity is similar to what entrepreneurs do in trying to identify entrepreneurial opportunities. Also, entrepreneurs have to engage in these types of creativity-relevant processes to discover opportunities and exploit them. The creation, funding, development, and growth of new ventures all require a great deal of creativity. An entrepreneur has to be creative in order to develop a new idea, seek venture capital funding, and pitch their idea to potential investors.

Creative ideas could either be modifications to existing processes (incremental) or significant breakthroughs (radical). Similarly, exploration is a firm behavior that is characterized by search, discovery, experimentation, risk taking, and innovation, while exploitation encompasses behaviors such as refinement, implementation, efficiency, production, and preference among choices (Hirst et al., 2009). The application of creative ideas to new business ventures inform of creation of new markets, new products and services, 
and new firms could be regarded as entrepreneurship (Eckhardt \& Shane, 2003). However, the literature on innovation and creativity literature talked about the natural tension between exploration and exploitation for firms or the likely benefits and costs of trying to develop more radical ideas (Zhou, Shalley, \& Hitt, 2015). Generally, explorative innovations have a potential higher failure rate than exploitative innovations. While, incrementally creative ideas are more likely to be effectively implemented than their more radical counterparts (Zhou et al., 2015) and Innovation start from using new knowledge or reusing and combining existing knowledge realized from creativity (Anderson, Potočnik, \& Zhou, 2014).

Creativity motivates the generation of new ideas and is considered one of the necessary determinants of innovation (Amabile, 1988: Im et al., 2013). In this study idea generation and implementation are acknowledged as two distinguishable elements of the innovation process, the current study examines the relationship between each of this construct and firm performance. In contrast to some earlier work, however, the focus here is not on the extent to which individuals develop ideas, irrespective of their novelty and usefulness, but rather on the overall creativity and firm performance relationship.

\section{Firm Performance}

Firm performance is the outcome achieved by combining organizational resources and capabilities through innovation process. It is the extent at which firms achieve their strategic and financial objectives (Cavusgil \& Zou, 1994). All the innovative activities must result in better firm performance compare to companies that do not innovate. Firm performance is measured with different concepts. Usually, firm- or economic-performance measures comprises of sales per employee, return on investment, total assets , export per employee, total employment, growth rates of sales, and operation profit ratio (Conceição, Gibson, Heitor, \& Sirilli, 2001). Even though objective measures on business performance are more accurate than subjective measure evaluation approaches, however, the collection of objective measure is characterized with difficulty, such as owner manager reluctance to open the financial information of the firm for inspection and wide variations in firm performance among SMEs which compound consistent analysis of result (Sapienza, Smith \& Canon 1988).

A firm could choose to trade-off long-term growth for short-term profitability, for instance, growth's measure of performance might be more accurate and accessible than accounting measures of financial performance (Zahra, 1991). In some prior studies growth is used as a proxy for business performance (Brush \& Vanderwerf, 1992; Tsai, MacMillan, \& Low, 1991). This study subscribes to the view that performance is multidimensional to capture different aspects of small business performance, the measure of Zou, Taylor and Osland (1998) addressed the three critical issues in determining performance, their scale EXPERF was multidimentional and really centered on performance. It was built on Cavusgil and Zou (1994) and comprises three basic dimensions that are rooted in performance's literatures; financial, strategic and satisfaction's performance measure. The nine items adapted from Zou et al., (1998) are used to measure firm performance in this study because they reflect economic and non-economic factor that could easily show the performance of SMEs.

\section{Empirical Review}

The literature review in this section focused on a research question, trying to identify, appraise, select and synthesize all high quality research evidence and arguments relevant to the research question. Review of literature on creativity and firm performance in this present 
study shows that the attentions of the prior studies have been concentrated on the antecedents of creativity, and very little is known about the relationship between creativity and firm performance. Nevertheless, the available studies are shown to provide critical insight between what is available and area that is needed to be explored

To begin with early literature, Amabile (1983) examined Organizational factors influencing individual creativity using Content analysis on 120 research-and development scientists from more than 20 corporations. The study stressed the formerly ignored social factors and highlights the contributions that a social psychology of creativity could make to an all-inclusive view of creative performance. This study did not draw a relationship between creativity and firm performance. In a similar study Amabile, Conti, Coon, Lazenby, and Herron (1996) focused on development of the climate for creativity instrument using data collected from 306 (main test) and 160 (validation test) team members and LISREl multivariate analysis to analyze the data. The results of the study show that perceived work environments assessed by the keys scales, discriminate between high-creativity projects and low-creativity projects.

Based on creativity enquiry, Andrews and Smith (1996) focused on determinants of MP creativity using regression analysis method on data collected from 193 product managers. The results of the study shows MP creativity is influenced by individual problem solving input, motivational factors, and situational factors. The study did not treat creativity as a precursor of innovation or construct that could even enhance firm performance. Moreover, Besemer and O'QUIN (1986) examined the development of a semantic scale of creativity, having used CFA on data collected from 133 students the result of the study shows how output perspective of creativity could be evaluated by three dimensions of creativity namely novelty, resolution, and elaboration.

Haberland and Dacin (1992) attempted to lay the foundations for the systematic evaluation of viewers' reaction to creative and less creative ads, having developed and tested a measure of viewers' judgments of the creativity on an advertisement. The result of this exploratory study shows that the measure has good psychometric properties and the ability to classify ads a priori as more or less creative. This study is also different from the focus of this study because its attention was merely on creative capability on advertisement. In similar study, Sethi, Smith, and Park (2001) examined determinants of NP creativity in NP team context using regression on data collected from 141 managers of NP teams. The outcome of the study shows that new product creativity is related to team characteristics and contextual influence. Another study, Moorman and Miner (1997) focused on Organizational memory on NP performance and creativity, using regression on 92 sets of data from managers in advertising companies. The results of this study show Organizational memory improve short-term financial performance of NPs while memory dispersion improves both the financial performance and the creativity of NPs. The study stressed on only the antecedents of creativity and not on how creativity could directly influences firm performance.

In another organizational study, Woodman, Sawyer, and Griffin (1993) investigated the links among creative persons, processes, and products, having carried out extensive content analysis on the constructs, organizational creativity is defined as the creation of valuable NP, service, idea, procedure, or process by persons working together in a complex social system Individual, group, and organizational characteristics influence creative behavior, which determines organizational creativity. This study focused on determinant of creativity in organization as against how creativity could directly impact on performance of SMEs 
Distinct from the above study and innovative but different from the major focus of this study, Baer (2012) examined the relationship between creativity and implementation and ability to network using data collected from 216 employees, the results of the study show that individuals were able to improve the negative odds of their creative ideas being realized when they expected positive outcomes to be associated with their implementation. Focusing on employee creativity, Liao, Liu, and Loi (2010) explained how and when the quality of social exchange relationships with a supervisor and fellow team members affect individual creativity in work teams. Using data collected from 828 employees. The results of the study show that LMX and TMX have unique indirect effects on employee creativity.

Furthermore, Amabile, Barsade, Mueller, and Staw (2005) examined how affectcreativity relates to creativity at work. Using both quantitative and qualitative longitudinal data from the daily diaries of 222 employees in seven companies, they examined the nature, form, and temporal dynamics of the affect-creativity relationship. The results indicate that positive affect relates positively to creativity in organizations and that the relationship is a simple linear one. This study did not draw direct relationship between creativity and firm performance.

Similarly, Kurtzberg and Amabile (2001) examined the specific group processes and dynamics that may affect team-level creative production and present a description of the ways in which diversity and different types of conflict in groups may affect the creative process. In the same vein, McAdam and McClelland (2002) also provided a critique and review of the role of individuals and teams in idea generation as part of the overall organizational creativity and innovation process in order to determine organizational development needs and research agendas in this area. These two studies only focused on how either individual or group within the organization could boost creativity and innovation no direct link with SMEs' performance Çekmecelioğlu and Günsel (2013) study the relationships among individual creativity, creative climate and firm innovativeness. Using SPSS to analyze the data obtained from 181 employees in manufacturing firms in Turkey. The results of the study showed that both individual creativity and creative climate have positive effects on firm innovation. Here the authors showed creativity as precursor of innovation no direct relationship with firm performance. In creativity's study, Tierney and Farmer (2011) provided a longitudinal examination of the development of creative selfefficacy in an ongoing work context. Increase in employee creative role identity and perceived creative expectation from supervisors over a 6-month time period were associated with enhanced sense of employee capacity for creative work. The result of the study shows that increase in creative self-efficacy corresponded with increases in creative performance. Creative performance was the emphasis not SMEs performance.

Dong, Liao, Chuang, Zhou, and Campbell (2015) offered theoretical and empirical account of how and when customer empowering behaviors can motivate employee creativity (Aldaihani \& Ali, 2018). Having collected data from 380 hairstylists matched with 3550 customers in 118 hair salons. The results of the study showed that customer empowering behaviors positively related to employee creativity and supervisory empowering leadership enhance the indirect effect of customer empowering behaviors on employee creativity through state promotion focus.

Liu et al. (2011) examined how and when department leader abusive supervision may flow down organizational levels to undermine team member creativity. Having employed multiphase, multisource, and multilevel data, the result of the study shows that team leader abusive supervision mediates the negative relationship between department leader abusive 
supervision and team member creativity. This study focused on antecedents of creativity not consequence of creativity or how it can affect firm performance.

Michael, Hou, and Fan (2011) studied the relationships among creative self-efficacy, optimism, and innovative behavior as well as the moderating effect of optimism. Having collected data from 120 employees of a diet and beauty salon company in Taiwan, the outcome of the longitudinal study shows that employees with a high level of creative selfefficacy exhibit a high level of innovative behavior at work. Creative self-efficacy was shown as precursor of innovation rather than SMEs' performance.

Im and Workman (2004) examined the mediating role of NP and MP creativity between market orientation and NP success and whether market orientation facilitates or inhibit creativity and whether creativity influences NP performance. Having used two-stage sampling frame to gather data from 312 managers and NP team leaders, the results of the study show that NP and MP creativity mediates the relationship between market orientation and new product success. Meaningfulness dimension of creativity is significantly related in the link between market orientation and new product success. Even though this study is related to the focus of the present student yet, different in terms of perceiving creativity as only antecedent of product success but ignored creativity as a stimulant of SMEs' performance.

Im et al. (2013) examined the intermediary role of creativity as a critical link between team dynamics and product competitive advantage, focusing on NP and marketing program (MP) creativity in product innovation teams and using data collected from 206 senior managers in high-tech manufacturing firms in United States. Structural equation model was used empirically to test the model. The results of this study show that creativity-novelty and meaningfulness are affected by team dynamics. NP novelty is influenced by external team factors such as market-based reward system and planning process formalization. NP meaningfulness is influenced by internal team factors.

Having reviewed the studies that are centered on antecedents of creativity an organization, there is a need to review some studies that implied creativity as direct precursor of firm performance, Gong, Zhou, and Chang (2013) examined when creativity is positively or negatively related to firm performance, using data collected from 761 core knowledge employees. The results of the study revealed that core knowledge employee creativity was negatively related to firm performance when riskiness orientation was high. While the relationship was positive when absorptive capacity was high and the relationship was also more positive in small firms than large firms. This study related creativity directly to firm performance but the study was not situated within SMEs' performance only it incorporated larger organization's core knowledge of employee which could not allow critical conclusion to be drawn.

In the same way, Von Nordenflycht (2007) observed the relationship between creativity and firm performance in 122 U.S. advertising agencies determining a positive, linear relationship between employee creativity and firm performance. It is generally believed that creativity results in competitive differentiation. This study also passed similarity test, but different in terms of the focus of this study. The focus of this study is not manufacturing SMEs

Barely all the literatures that were readily available as at the time of writing this paper did not draw direct link between creativity and SMEs performance most especially the SMEs that manufacturing one goods or the other. Regardless of the possible importance of creativity in many firms, the relationship has not attracted much research attention in 
management and entrepreneurship literature (Gilson, 2008). However, Creativity has been described as the generation of novel and useful ideas (Amabile, 1996).

Before creative ideas could enhance firm performance, they have to be implemented, that is, turned into tangible products and practices and incorporated into operations (Gong et al, 2013). However, the stage model makes a broad distinction between idea generation and idea implementation (West, 2002). Through implementation activities, creative ideas are evaluated, turned into workable products, and incorporated into an organization's practices (Gilson \& Shalley, 2004 (Gilson \& Shalley, 2004; Zhang \& Bartol, 2010b).

Consequently, the major focus on the determinants of creativity, however, has led to too little awareness of aftermath effect of creativity (Gong et al., 2009; Zhou \& Shalley, 2008). Employee creativity could make a significant contribution to a firm's competitive performance (Baer \& Oldham, 2006). Creative efforts of people could make an important contribution to SMEs performance. Hence, internal operations, external demands, procedures and products of Manufacturing SMEs could be improved through creative ideas (Gilson, 2008). Moreover, creativity could culminate to uniqueness, product quality/differentiation, cost effectiveness, and technical efficiency in SMEs which is an important determinant of a firm's performance (Woodman et al., 1993). Firms that demonstrate creative behaviors generate competitive advantages and better performances than its competitors (Woodman et al., 1993). Most especially firms with outstanding employee's creativity perform better (Tierney and Farmer, 2004). There is empirical support for the impact of creativity on revenue growth rates (Von Nordenflycht 2007).

People's creative efforts have been described as important contributions to firm performance (Redmond, Mumford, \& Teach, 1993). Employee creativity could also make a substantial contribution to firm competitiveness (Baer and Oldham, 2006). Creativity that focuses on meaningfulness and novelty in the activities of SMEs would provide a competitive advantage. Meaningfulness and novelty in design of products and activities would also improves the performance of SMEs and enhance customer loyalty and satisfaction (Andrews and Smith 1996; Gong et al., 2013; Aldaihani \& Ali, 2018). Consistent with IM et al. (2004), (2013), and Amiable (1983) this study adopts productive/output perspective of creativity, which identifies two discrete dimensions of creativity as outcome standard. Novelty in the degree to which outputs are perceived as new and different from those of competitors and meaningfulness is the extent to which outputs are perceived as appropriate and useful by the targeted audience. Novelty and meaningfulness are unanimous among scholars as dimensions of creativity (Im et al., 2013). Hence, this study is distinct from other studies (IM et al. 2004; IM et al., 2013; Amiable, 1983) using novelty and meaningfulness as antecedent and consequence of SME's performance.

Theoretically, the resource-based View of the firm suggests that creativity, which is an intangible resource entrenched within the firm, could provide a competitive advantage (Barney 1991). Therefore, creativity as rare, valuable, non-substitutable, and inimitable property of the firm could render sustainable competitive advantage. Hence this study hypothesizes that;

H1: Meaningfulness is significantly and positively related to performance of SMEs. $\mathrm{H} 2$ : Novelty is significantly and positively related to performance of SMEs 


\section{Measures}

\section{Research Methodology}

Creativity entails generation of ideas that are both novel and useful for practical purpose (Amabile, 1996; Shalley et al., 2004). It is a process of variation, selection and retention of idea that are most promising. Novelty is the degree to which outputs are perceived as new and different from those of competitors while meaningfulness is the extent to which outputs are perceived as appropriate and useful by the targeted audience. Novelty and meaningfulness are unanimous among scholars as dimensions of creativity (Im et al., 2013). Novelty is measured based on firm's new products and marketing programs compared with that of its competitors and anchored on seven-point, six-item scale while meaningfulness's measures are based on how meaningful firm's new products and marketing programs are when compared with that of its competitors. This is also anchored on seven-point, four-item scale. Table 3.5 depicts the measures of novelty

Table 3.5: Measures of Novelty

\begin{tabular}{|c|c|c|c|c|}
\hline Construct & Dimensions & Code & Survey Items & Sources \\
\hline \multirow[t]{6}{*}{ creativity } & Novelty & CNO01 & Our products are really out of the ordinary & Im et al., 2013 \\
\hline & & $\mathrm{CNO} 02$ & $\begin{array}{l}\text { Our products can be considered as } \\
\text { revolutionary }\end{array}$ & \\
\hline & & CNO03 & Our product is stimulating. & \\
\hline & & $\mathrm{CNO} 04$ & $\begin{array}{l}\text { We reflect customary perspectives in this } \\
\text { industry }(\mathrm{R}) \text {. }\end{array}$ & \\
\hline & & CNO05. & $\begin{array}{l}\text { Our firms provides radical differences from } \\
\text { industrial norms }\end{array}$ & \\
\hline & & CNO06 & $\begin{array}{l}\text { Our firm always show unconventional way of } \\
\text { solving problems }\end{array}$ & \\
\hline
\end{tabular}

Meaningfulness's measures are based on how meaningful firm's new products and marketing programs are when compared with that of its competitors. This is also anchored on seven-point, four-item scale.

Table 3.5.2: Measures of Meaningfulness

\begin{tabular}{lllll}
\hline Construct & Dimensions & Code & Survey Items & Sources \\
\hline Creativity & Meaningfulness & CMO01 & $\begin{array}{l}\text { Our firm's products and activities are } \\
\text { relevant to customer's needs and } \\
\text { expectation. }\end{array}$ & Im et al., (2013) \\
CMO02 & $\begin{array}{l}\text { Our firm's products are considered } \\
\text { suitable for customers' desires } \\
\text { Our products are appropriate for } \\
\text { customers' needs and expectations } \\
\text { Cur products and activities are useful } \\
\text { CMO04 }\end{array}$ & \\
& &
\end{tabular}

The measurement of firm performance has not been universally suggested among scholars, Zou, Taylor and Osland (1998) addressed the three critical issues in determining performance, their scale EXPERF was multidimentional and really centered on performance. It was built on Cavusgil and Zou (1994) and comprises three basic dimensions that are rooted in performance's literatures; financial, strategic and satisfaction's performance measure. 
The nine items adapted from Zou et al., (1998) are used to measure firm performance in this study because they reflect economic and non economic factor that could easily show the performance of SMEs. These nine items adapted from Zou et al., (1998) called EXPERF scale is shown in the Table 3.8.

Table 3.8 : Measures of SMEs Performance

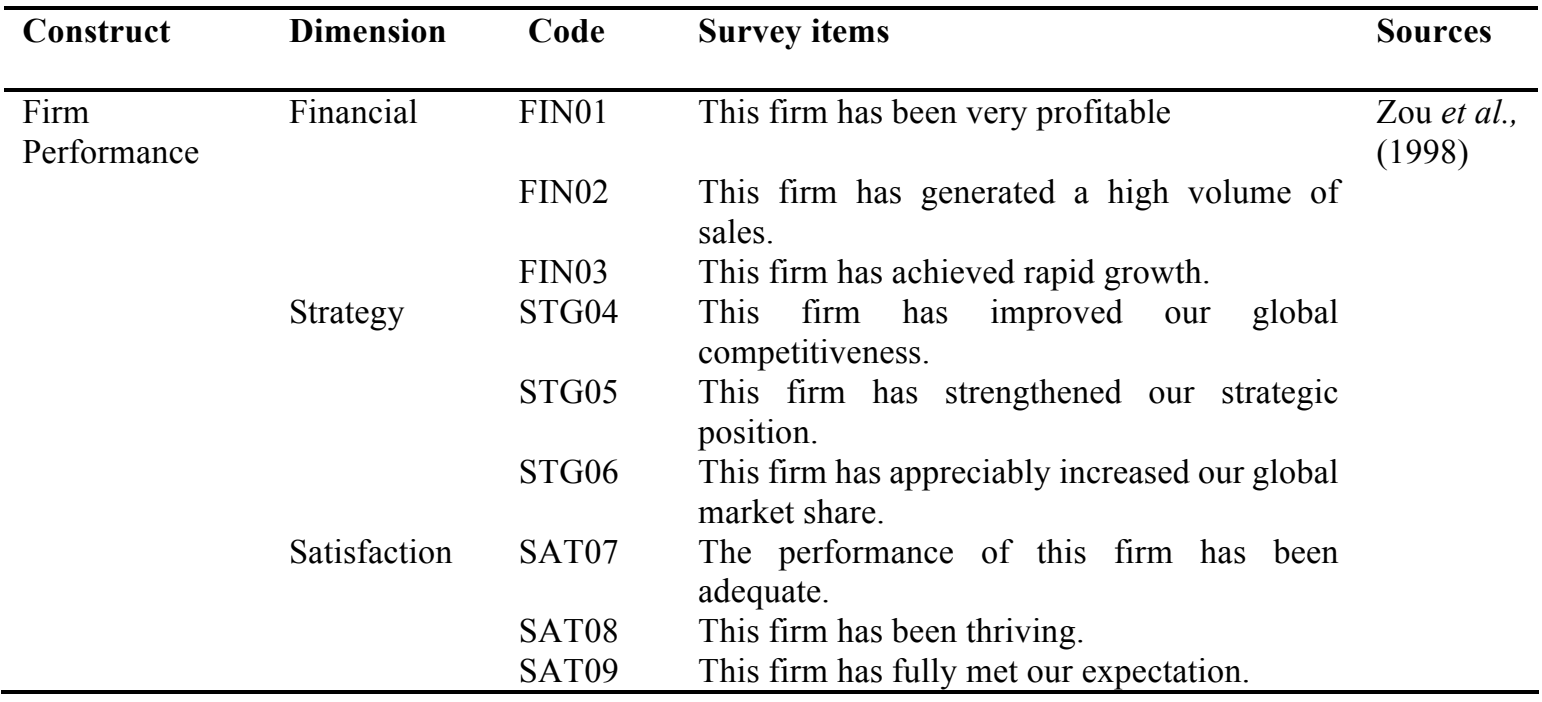

\section{Data Collection Process}

This study employed a descriptive survey design and data were collected from primary source using questionnaire. The population for this study consists of all SMEs in Lagos State. Due to lack of statistics as to the total number of SMEs in Lagos state, it was difficult to correctly ascertain the total number of SMEs in Lagos state. The population size was however pinned down to the number of SMEs registered with Corporate Affairs Commission. The registered SMEs in Lagos state was about 3,390. The registration was classified according to different sectors or industries such as food beverage, manufacturing, machinery, paper and printing, plastic, services and. The separation of businesses by sector will ensure that representatives of businesses from each industry are included

Simple random sampling was used to get the sample for this study. This type of sampling design also has least bias and any subsequent findings can be generalized (Sekaran, 2003). Sekaran (2003) sample size decision was used to ensure good decision model. For population 3,390, the appropriate sample size according to sample size decision table is 300 . In total 360 questionnaires were distributed to the respondents, 120 were collected personally. The questionnaires were completed by accounting managers, accountants, accounting staffs, financial managers and businesses owners. However, only 100 respondents were considered as usable for the purpose of data analysis. The remaining 260 sets of questionnaires were excluded from data analysis because they were incomplete, totally blank or have not been returned

\section{Factor Analysis for Novelty}

\section{Results and Analysis}

Factor Analysis conducted for novelty. This variable is consisting of 6 items. The KMO test for firm performance recorded .735 which is considered as good and Barlett tests with sig. value 0.000 . Table 4.1 shows the KMO and Bartlett's Test for novelty while Table 4.2 shows 
the factor loading for 6 items which are all greater than the recommended 0.5 ; this shows distribution of the values is standard

Table $4.1:$ KMO and Barlett's Test Novelty

Kaiser-Meyer-Olkin Measure of Sampling Adequacy.

Bartlett's Test of Sphericity

\begin{tabular}{l|l} 
Df & 6 \\
Sig. & .000 \\
\hline
\end{tabular}

Table 4.2: Component Matrix of Novelty

\begin{tabular}{|l|l|l|l|l|}
\hline Name & Items & Factors Loading & Eigen value & \% variance \\
\hline Novelty & Really out of ordinary. & .798 & 2.254 & 56.342 \\
\hline & Revolutionary products. & .551 & & \\
\hline & Stimulating products. & .843 & & \\
\hline & $\begin{array}{l}\text { Reflection of customer } \\
\text { perspectives }\end{array}$ & .775 & & \\
\hline $\begin{array}{l}\text { Radical difference from } \\
\text { industrial norms }\end{array}$ & $\begin{array}{l}\text { Unconventional way of } \\
\text { solving problems }\end{array}$ & .587 & & \\
\hline
\end{tabular}

In Table 4.3 the KMO test for firm performance recorded .809 which is considered as good and Barlett tests with sig. value 0.000 .

Table 4.3: KMO and Bartlett's Test

\begin{tabular}{|c|c|c|}
\hline \multicolumn{2}{|c|}{ Kaiser-Meyer-Olkin Measure of Sampling Adequacy. } & .809 \\
\hline \multirow{3}{*}{ Bartlett's Test of Sphericity } & Approx. Chi-Square & 213.678 \\
\hline & Df & 10 \\
\hline & Sig. & .000 \\
\hline
\end{tabular}

Table 4.4 shows Meaningfulness, the factor loading for all items are all greater than the recommended 0.5 ; this shows that the distribution of the values is standard

Table 4.4 KMO and Barlett's of Meaningfulness

\begin{tabular}{|c|c|c|c|c|}
\hline Name & Items & $\begin{array}{l}\text { Factors } \\
\text { Loading }\end{array}$ & Eigen value & $\%$ variance \\
\hline \multirow[t]{4}{*}{ Meaningfulness } & $\begin{array}{l}\text { Products are relevant to } \\
\text { customers' needs }\end{array}$ & .832 & 2.922 & 58.447 \\
\hline & $\begin{array}{l}\text { Products are considered } \\
\text { for customers' desire }\end{array}$ & .835 & & \\
\hline & $\begin{array}{l}\text { Products are appropriate } \\
\text { for customers' needs and } \\
\text { expectation }\end{array}$ & .621 & & \\
\hline & $\begin{array}{l}\text { Products and activities } \\
\text { are useful for customers }\end{array}$ & .755 & & \\
\hline
\end{tabular}




\section{Reliability}

Reliability is a measuring instrument that measures the consistency of an instrument (Sekaran \& Bougie, 2010). The reliability of the instrument used in this study was tested using the Cronbach's Alpha. Table 4.5 shows the reliability result of this study.

Table 4.5: Summary of Reliability of the variables of the study

\begin{tabular}{|l|l|l|}
\hline Variables & No of Items & Reliabilty Cronbach Alpha \\
\hline Firm Performance & 7 & .847 \\
\hline Novelty & 7 & .818 \\
\hline Meaningfulness & 4 & .819 \\
\hline
\end{tabular}

The lowest limit of the value of Cronbach's Alpha is 0.70 (Hair, Anderson, Tatham \& Black, 1998). The range of 0 to 1 indicates Cronbach's Alpha coefficients of dependability of the data. Therefore, considering the above table, the value of Cronbach's Alpha ranging from 0.818 to 0.847 where the value is closer to 1 . This shows that this data has higher reliability of internal consistency (Sekaran, 2003).

Table 4.6: Correlation Among Constructs

\begin{tabular}{|l|l|c|c|}
\hline Variables & DV & IV1 & IV2 \\
\hline Firm Performance & 1 & & \\
\hline Novelty & $.397^{* *}$ & 1 & \\
\hline Meaningfulness & $.356^{* *}$ & $.262^{* *}$ & 1 \\
\hline
\end{tabular}

**Correlation is significant at the level 0.01 (2-tailed)

\section{Regression}

Multiple regressions were carried out to identify the independent variables as well as the Contribution of these dimensions; novelty and meaningfulness in predicting firm performance. The finding of the multiple regressions based on statistical assessment is shown below. The two independent variables explained 59.7\% $(\mathbf{R 2}=.597)$ of total variance in firm performance. The two variables have significant values and explain firm performance. They have the highest beta values as follows; novelty $(\beta=.443, p<.000)$ and meaningfulness $(\beta=.188, \mathrm{p}<.018)$.

Table 4.8: Regression Analysis

\begin{tabular}{|l|l|l|l|l|}
\hline Independent variables & Beta $(\boldsymbol{\beta})$ & $\mathbf{t}$ & Sig. & Std. Deviation \\
\hline Meaningfulness & $.188 * * *$ & 2.405 & .018 & .570 \\
\hline Novelty & $.443 * * *$ & 6.178 & .000 & .527 \\
\hline
\end{tabular}

$* p<0.1 * * p<0.05 * * * p<0.0$

Table 4: Summary of Hypotheses Results

\begin{tabular}{|l|l|l|}
\hline & Hypothesis & Result \\
\hline H1 & There is positive influence of novelty towards firm performance & Accepted \\
\hline H2 & There is positive influence of meaningfulness towards firm performance & Accepted \\
\hline
\end{tabular}

\section{Discussions and Implications}

Researches on impact of creativity (meaningfulness and novelty) on firm performance have previously focused on large organizational Contexts, this study proposed the context of SMEs as a better litmus test of this relationship. This study hypothesized that (H1) there is 
positive relationship between novelty and firm performance, The result of regression analysis $(\beta=.443, p<.000)$ shows there is positive influence of novelty towards firm performance, Similarly, The study hypothesized that there is positive and significant relationship between meaningfulness and firm performance, the result of SPSS' regression analysis $(\beta=.188, \mathrm{p}<.018)$ depicts there is relationship between the two constructs. This result is consistent with prior studies (IM et al. 2004; IM et al., 2013; Amiable, 1983) Even though IM et al., 2013 and IM et al. 2004 were conducted in different context with different samples. The result of this study is clear demonstration that creativity in quest for entrepreneurial values would enhance SMEs' performance.

The focus of this study is not on the extent to which individuals develop ideas, irrespective of their novelty and usefulness, but rather on the overall creativity and firm performance relationship. Proactive creativity requires extending effort to widely scan the environment for potentially damaging problems that need solutions. This type of creativity is similar to what entrepreneurs do in trying to identify entrepreneurial opportunities. Also, entrepreneurs have to engage in these types of creativity-relevant processes to discover opportunities and exploit them. The creation, funding, development, and growth of new ventures all required a great deal of creativity. An entrepreneur has to be creative in order to develop a new idea, seek venture capital funding, and pitch their idea to potential investors. The application of creative ideas to new business ventures inform of creation of new markets, new products and services, and new firms could be regarded as entrepreneurship.

\section{Conclusion}

Novelty is the degrees to which outputs are perceived as new and different from those of competitors, novelty in design of products and activities would also improves the performance of SMEs and enhance customer loyalty and satisfaction (Andrews and Smith 1996; Gong et al., 2013). Having collected data from SMEs' practitioners in Nigeria to validate this assertion, the results of this study indicate positive and statistically significant relationship. Hence the owner managers of SMEs could avail themselves of novelty that would give rise to out of ordinary product/service, revolutionary product, stimulating product or service, product/service that reflects customer perspective in the industry and product/service that are radically different from industrial norms and improve firm performance and achieve sustainable competitive advantage.

Similarly, meaningfulness as aspect of creativity is the extent to which outputs are perceived as appropriate and useful by the targeted audience. Based on the outcome of this study, meaningfulness and firm performance have positive and significant statistical standard relationship. Hence, SMEs' practitioners could invest time and energy on creating products and activities that are relevant to customer's needs and expectation, products that are considered suitable for customers' desires, products that are appropriate for customers' needs and expectations and products and activities that are useful for customer in order to achieve sustainable competitive advantage.

\section{Research Limitation and Future Direction}

Most of the available studies on creativity in management literatures have tended to focus solely on the (product design and features) with no consideration of the role of creativity in associated with firm performance, Im, Montoya, \& Workman, (2013). Considered antecedents and consequences of creativity in product innovation, this study takes a radical departure by identifying and examining novelty and meaningfulness as components of creativity that directly translate into improved SMEs' performance. The limitation of this 
study could be seen on building on Im, Montoya, \& Workman, (2013), using meaningfulness and novelty as dimensions of creativity to predict firm performance relationship. Other variable could have been explored to reflect critical characteristics of creativity in SMEs and most especially creativity process in entrepreneurship. Fundamentally, four main processes of generating creative ideas; information, incubation, illumination and verification and how they could give rise SMEs performance. Similarly, creative techniques; brainstorming, forced analogy, do it, mind mapping, and nominal group could have been used to explain or predict SMEs' performance relationship

Nevertheless, the purpose of this study has been achieved, future studies could investigate main processes of generating creative ideas; information, incubation, illumination and verification and how they could give rise to SMEs performance and sustainable competitive advantage in less developed economy where there is dearth of these studies.

\section{References}

Acharya, P., \& Taylor, R. (2012). Innovative Deviance: An Investigation of the Relationships between Social Control, Creativity and Innovation in Organizations. Academy of Business Research Journal, 1(1) 49-58.

Aldaihani, F. M. F., \& Ali, N. A. B. (2018). Impact of Social Customer Relationship Management on Customer Satisfaction through Customer Empowerment: A Study of Islamic Banks in Kuwait. International Research Journal of Finance and Economics, (170). 41-53.

Aldaihani, F. M. F., \& Ali, N. A. B. (2018). Impact Of Relationship Marketing On Customers Loyalty Of Islamic Banks In The State Of Kuwait. International Journal of Scientific \& Technology Research. 8(11).

Amabile, T. M. (1988). A model of creativity and innovation in organizations. Research in organizational behavior, 10(1), 123-167.

Amabile, T. M. (1996). The motivation for creativity in organizations: Harvard Business School

Amabile, T. M. (1997). Entrepreneurial creativity through motivational synergy. The Journal of Creative Behavior, 31(1), 18-26.

Amabile, T. M. (1983). The social psychology of creativity: A componential conceptualization. Journal of personality and social psychology, 45(2), 357.

Amabile, T. M., Conti, R., Coon, H., Lazenby, J., \& Herron, M. (1996). Assessing the work environment for creativity. Academy of management journal, 39(5), 1154-1184.

Amabile, T. M. (1998). How to kill creativity: Harvard Business School Publishing Boston, MA.

Amabile, T. M., Barsade, S. G., Mueller, J. S., \& Staw, B. M. (2005). Affect and creativity at work. Administrative science quarterly, 50(3), 367-403

Anderson, N., Potočnik, K., \& Zhou, J. (2014). Innovation and creativity in organizations a state- of-the- science review, prospective commentary, and guiding framework. Journal of Management, 40(5), 1297-1333.

Andrews, J., \& Smith, D. C. (1996). In search of the marketing imagination: Factors affecting the creativity of marketing programs for mature products. Journal of Marketing Research, 174-187.

An, W., Zhang, J., You, C., \& Guo, Z. (2018). Entrepreneur's creativity and firm-level innovation performance: bricolage as a mediator. Technology Analysis \& Strategic Management, 30(7), 838-851. 
Axtell, C., Holman, D., \& Wall, T. (2006). Promoting innovation: A change study. Journal of Occupational and Organizational Psychology, 79(3), 509-516.

Axtell, C. M., Holman, D. J., Unsworth, K. L., Wall, T. D., Waterson, P. E., \& Harrington, E. (2000). Shopfloor innovation: Facilitating the suggestion and implementation of ideas. Journal of occupational and organizational psychology, 73(3), 265285.

Baer, M. (2012). Putting creativity to work: The implementation of creative ideas in organizations. Academy of Management Journal, 55(5), 1102-1119.

Baer, M., \& Oldham, G. R. (2006). The curvilinear relation between experienced creative time pressure and creativity: moderating effects of openness to experience and support for creativity. Journal of Applied Psychology, 91(4), 963.

Barney, J. (1991). Firm resources and sustained competitive advantage. Journal of management, 17(1), 99-120

Besemer, S., \& O'Quin, K. (1986). Analyzing creative products: Refinement and test of a judging instrument. The Journal of Creative Behavior, 20(2), 115-126.

Bledow, R., Frese, M., Anderson, N., Erez, M., \& Farr, J. (2009). A dialectic perspective on innovation: Conflicting demands, multiple pathways, and ambidexterity. Industrial and Organizational Psychology, 2(3), 305-337.

Brush, C. G., \& Vanderwerf, P. A. (1992). A comparison of methods and sources for obtaining estimates of new venture performance. Journal of Business venturing, $7(2), 157-170$.

Cavusgil, S. T., \& Zou, S. (1994). Marketing strategy-performance relationship: an investigation of the empirical link in export market ventures. The Journal of Marketing, 1-21.

Chen, M. H., Chang, Y. Y., \& Lin, Y. C. (2018). Exploring creative entrepreneurs' happiness: cognitive style, guanxi and creativity. International Entrepreneurship and Management Journal, 14(4), 1089-1110.

Conceição, P., Gibson, D. V., Heitor, M. V., \& Sirilli, G. (2001). Beyond the digital economy: A perspective on innovation for the learning society. Technological Forecasting and Social Change, 67(2), 115-142.

Çekmecelioğlu, H. G., \& Günsel, A. (2013). The effects of individual creativity and organizational climate on firm innovativeness. Procedia-Social and Behavioral Sciences, 99, 257-264

Culpepper, M. K. (2010). KEYS to creativity and innovation: an adopt-a-measure examination. The International Center for Studies in Creativity, 1-19.

Clegg, C., Unsworth, K., Epitropaki, O., \& Parker, G. (2002). Implicating trust in the innovation process $\dagger$. Journal of Occupational and Organizational Psychology, 75(4), 409-422.

Dong, Y., Liao, H., Chuang, A., Zhou, J., \& Campbell, E. M. (2015). Fostering Employee Service Creativity: Joint Effects of Customer Empowering Behaviors and Supervisory Empowering Leadership

Eckhardt, J. T., \& Shane, S. A. (2003). Opportunities and entrepreneurship. Journal of management, 29(3), 333-349.

Gilson, L. L. (2008). Why be creative: A review of the practical outcomes associated with creativity at the individual, group, and organizational levels. Handbook of organizational creativity, 303-322 
Gilson, L. L., \& Shalley, C. E. (2004). A little creativity goes a long way: An examination of teams' engagement in creative processes. Journal of management, 30(4), 453- 470.

Gong, Y., Huang, J.-C., \& Farh, J.-L. (2009). Employee learning orientation, transformational leadership, and employee creativity: The mediating role of employee creative self- efficacy. Academy of Management Journal, 52(4), 765-778.

Gong, Y., Zhou, J., \& Chang, S. (2013). Core knowledge employee creativity and firm performance: The moderating role of riskiness orientation, firm size, and realized absorptive capacity. Personnel Psychology, 66(2), 443-482.

Haberland, G. S., \& Dacin, P. A. (1992). The development of a measure to assess viewers' judgments of the creativity of an advertisement: A preliminary study. Advances in consumer research, 19(1), 817-825

Hair, J. F., Anderson, R. E., Tatham, R. L., \& Black, W. C. (1998). Multivariate Data Analysis, Prentice Hall. Upper Saddle River, NJ, 730

Hirst, G., Van Knippenberg, D., \& Zhou, J. (2009). A cross-level perspective on employee creativity: Goal orientation, team learning behavior, and individual creativity. Academy of Management Journal, 52(2), 280-293.

Im, S., Montoya, M. M., \& Workman, J. P. (2013). Antecedents and consequences of creativity in product innovation teams. Journal of Product Innovation Management, 30(1), 170-185.

Kao, J. J. (1997). The art \& discipline of business creativity. Strategy \& Leadership, 25(4), 6-11.

Kurtzberg, T. R., \& Amabile, T. M. (2001). From Guilford to creative synergy: Opening the black box of team-level creativity. Creativity Research Journal, 13(3-4), 285-294.

Liao, H., Liu, D., \& Loi, R. (2010). Looking at both sides of the social exchange coin: A social cognitive perspective on the joint effects of relationship quality and differentiation on creativity. Academy of Management Journal, 53(5), 1090-1109.

Lin, Y.-S. (2011). Fostering creativity through education-a conceptual framework of creative pedagogy. Creative education, 2(03), 149

Liu, D., Chen, X.-P., \& Yao, X. (2011). From autonomy to creativity: a multilevel investigation of the mediating role of harmonious passion. Journal of Applied Psychology, 96(2), 294

Im, S., \& Workman Jr, J. P. (2004). Market orientation, creativity, and new product performance in high-technology firms. Journal of marketing, 68(2), 114-132.

Martins, E., \& Terblanche, F. (2003). Building organisational culture that stimulates creativity and innovation. European journal of innovation management, 6(1), 64-74

McAdam, R., \& McClelland, J. (2002). Individual and team-based idea generation within innovation management: organisational and research agendas. European Journal of Innovation Management, 5(2), 86-97.

Michael, L. H., Hou, S. T., \& Fan, H. L. (2011). Creative Self-Efficacy and Innovative Behavior in a Service Setting: Optimism as a Moderator. The Journal of Creative Behavior, 45(4), 258-272.

Moorman, C., \& Miner, A. S. (1997). The impact of organizational memory on new product performance and creativity. Journal of marketing research, 91-106. 
Redmond, M. R., Mumford, M. D., \& Teach, R. (1993). Putting creativity to work: Effects of leader behavior on subordinate creativity. Organizational behavior and human decision processes, 55(1), 120-151

Sathikh, P. M. (2014). What are you managing in design? Creativity or Innovation or Both?

Sekaran, U. (2003). Research Methods For Business, A Skill Building Approach, John Willey \& Sons. Inc. New York.

Sekaran, U., \& Bougie, R. (2010). Theoretical framework in theoretical framework and hypothesis development. Research methods for business: A skill building approach, 80

Sethi, R., Smith, D. C., \& Park, C. W. (2001). Cross-functional product development teams, creativity, and the innovativeness of new consumer products. Journal of Marketing Research, 38(1), 73-85.

Shalley, C. E., \& Zhou, J. (2008). Organizational creativity research: A historical overview. Handbook of, 1.

Shalley, C. E., Zhou, J., \& Oldham, G. R. (2004). The effects of personal and contextual characteristics on creativity: Where should we go from here? Journal of management, 30(6), 933-958.

Shahzad, K., Bajwa, S. U., Siddiqi, A. F. I., Ahmid, F., \& Sultani, A. R. (2016). Integrating knowledge management (KM) strategies and processes to enhance organizational creativity and performance. Journal of modelling in management

Sapienza, H. J., Smith, K. G., \& Gannon, M. J. (1988). Using subjective evaluations of organizational performance in small business research. American Journal of Small Business, 12(3), 45-54.

Simonton, D. K. (2011). Creativity and discovery as blind variation: Campbell's (1960) BVSR model after the half-century mark. Review of General Psychology, 15(2), 158.

Tierney, P., \& Farmer, S. M. (2004). The Pygmalion process and employee creativity. Journal of Management, 30(3), 413-432.

Tierney, P., \& Farmer, S. M. (2011). Creative self-efficacy development and creative performance over time. Journal of Applied Psychology, 96(2), 277.

Tsai, W. M.-H., MacMillan, I. C., \& Low, M. B. (1991). Effects of strategy and environment on corporate venture success in industrial markets. Journal of business venturing, 6(1), 9-28.

van Esch, E., Wei, L. Q., \& Chiang, F. F. (2018). High-performance human resource practices and firm performance: The mediating role of employees' competencies and the moderating role of climate for creativity. The International Journal of Human Resource Management, 29(10), 1683-1708.

Von Nordenflycht, A. (2007). Is public ownership bad for professional service firms? Ad agency ownership, performance, and creativity. Academy of Management Journal, 50(2), 429-445.

West, M. (1997). Developing Creativity in Organizations: Personal and Professional Development: Wiley-Blackwell.

West, M. A. (2002). Sparkling fountains or stagnant ponds: An integrative model of creativity and innovation implementation in work groups. Applied psychology, $51(3), 355-387$

Wu, C. (2016). Entrepreneurial leadership, organisational creativity, and firm performance in Chinese SMEs context (Doctoral dissertation, University of Nottingham) 
Woodman, R. W., Sawyer, J. E., \& Griffin, R. W. (1993). Toward a theory of organizational creativity. Academy of management review, 18(2), 293-321

Zhang, X., \& Bartol, K. M. (2010a). The influence of creative process engagement on employee creative performance and overall job performance: a curvilinear assessment. Journal of Applied psychology, 95(5), 862.

Zahra, S. A. (1991). Predictors and financial outcomes of corporate entrepreneurship: An exploratory study. Journal of business venturing, 6(4), 259-285.

Zhou, J., Shalley, C. E., \& Hitt, M. A. (2015). The Oxford Hand Book on Innovation, Creativity and Entrepreneurship. USA: Oxford University Press.

Zou, S., Taylor, C. R., \& Osland, G. E. (1998). The EXPERF scale: a cross-national generalized export performance measure. Journal of international Marketing, 6(3), 37-58. 